\title{
Space Based Spatio-Temporal Assessment of Land Surface Temperature in Karunagappally Municipality, a Fast Growing City in the Western Coast of India
}

\author{
Sumith Satheendran S. ${ }^{12,}{ }^{*}$, Smitha Chandran S. ${ }^{1}$, Abin Varghese ${ }^{2}$ \\ ${ }^{1}$ Department of Chemistry, Amrita Viswa Vidyapeetham, Amritapuri Campus, Kerala, India - smithachandran@am.amrita.edu \\ ${ }^{2}$ Dr. R. Satheesh Centre for Remote Sensing and GIS, Mahatma Gandhi University, Kerala, India -remotesumithsat@gmail.com
}

\author{
Commission V, SS: Infrastructure and Development Planning
}

Keywords: Landsat, Thermal Band, Brightness Temperature, Karunagappally, Land Surface Temperature, Spatio-Temporal

\begin{abstract}
Urbanization is the process by which towns and cities are formed and become larger as more and more people begin living and working in central areas. According to 2001 census, the urban population of the country was 286.11 million, living in 5161 towns, which constitutes $27.81 \%$ of the total country's population. However, the same as per 2011 census has risen to 377.16 million viz. $32.16 \%$ of the total country's population and the number of towns has gone up to 7935 . The rate of urban growth in the country is very high as compared to developed countries, and the large cities are becoming larger mostly due to continuous migration of population to these cities. India's current urban population exceeds the whole population of the United States, the world's third largest country. By 2050, over half of India's population is expected to be urban dwellers. This creates enormous pressure on existing urban infrastructure.

Urbanization trend in the State of Kerala shows marked peculiarities. The main reason for urban population growth is the increase in the number of urban areas and urbanization of the peripheral areas of the existing major urban centers. However, unlike the other parts of the country the Urbanization in Kerala is not limited to the designated cities and towns. The difference between rural and urban agglomerations is very negligible as far as Kerala is concerned. The Kerala society by and large can be termed as urbanized. Kerala has been witnessing rapid urbanization since 1980.

The present study, is an attempt to analyses the extent of land use/ land cover changes in the Municipality over the years from 2012 to 2017 and land surface variation over the years from 2000 to 2017.The land use/ land cover pattern of 2012 to 2017 was extracted from High resolution images of the study area were downloaded from Google Earth API and the Land Surface Temperature changes were analyzed from the thermal bands of the Landsat Imageries.
\end{abstract}

\section{INTRODUCTION}

\subsection{The present study area}

Karunagappally is a city in Kollam district of the Indian State of Kerala. The place has beautiful backwaters, which connects it to Kollam and Alappuzha. Padanayarkulangara, which forms part of the town, was once the military station of the Kayamkulam Rajas. An idol of Buddha, recovered from a local tank here, has raised speculations that Karunagappally was once a center of Buddhist teachings. The city is well connected by rail and road with other cities in the region. It has a thriving economy and boasts of welldeveloped commercial establishments and public infrastructure. Karunagappally is well known for its coir, fishing and tourism industries. It is an important township located on the backwaters of Kerala. The climate is tropical wet, with heavy rain in the monsoon season (May - August and October - November).

The geographical coordinates for Karunagappally extent from $9^{\circ} 3^{\prime} 11^{\prime \prime}$ to $\mathrm{N}$ latitudes and $76^{\circ} 32^{\prime} 4^{\prime \prime}$ to E longitudes (Figure 1). Karunagappally taluk covers an area of 66.34 $\mathrm{km}^{2}$. The taluk is bound on the north by Kayamkulam, east by Kunnathur taluk, south by Kollam and on the west by the Arabian Sea.

\footnotetext{
${ }^{*}$ Corresponding author
}

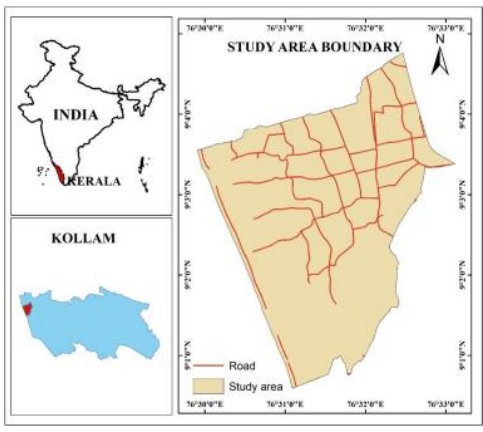

Figure 1 Study area

\subsection{Studies on land use land cover changes}

Land cover (LC) is defined as the features that are present on the earth's surface. Land use refers to the human induced changes for agricultural, industrial, residential or recreational purposes (Ramachandra and Bharath, 2012). Land cover changes refer to conversion and modification of vegetation, changes in biodiversity, soil quality, runoff, erosion, sedimentation and land productivity (Xiubin, 1996). Land use has been changing ever since humans first began to manage their environment. However, the changes that have taken place over the last 50 years have been especially important and intense as society is becoming increasingly urbanized, while natural ecosystems become deteriorated (Martinez et al., 2009). LULC changes are 
driven by the interaction of ecological, geographical, economic, and social factors (Zang and Huang, 2006) in the process of landscape development (Bürgi et al., 2004; Hersperger and Burgi, 2009). The interaction between biophysical and human dimensions in space and time is the main driver of Land use change. The possible impacts of land use/cover change on environment have inspired researchers to conduct research in order to understand main causes and effects of land use change (Veldkamp and Verburg, 2004).

Land use activities whether converting natural landscapes for human use or changing management practices on human dominated lands have transformed a large proportion of the Earths land surface. Due to clearing of tropical forests, practicing subsistence agriculture, increasing farmland production and expanding urban centers, the world's landscape is changing in inescapable ways through human actions (Foley et al., 2005). Although land-use practices vary greatly across the world, their final outcome is generally the same, the achievement of natural resources for immediate human needs, often at the expense of degrading environmental conditions.

Land-cover and land-use (LCLU) change analyses and projection provides a tool to assess ecosystem change and its environmental implications at various temporal and spatial scale (Lambin, 1997). Land use and Land cover (LULC) data provides useful information regarding developmental, environmental and resource planning applications at regional as well as global scale (Ramachandra et al., 2012). LULC dynamics are analyzed through changes in the state of an object or phenomenon by observing it at different times. Accurate and timely detection of change in natural resources provides the basic understanding of the relationships and interactions between human and natural phenomena. Satellite Remote Sensing data, which are a useful source of information and provides timely and complete coverage of any specific area, have proven useful in assessing the natural resources and monitoring the land use or land cover changes (Satyanarayana et al., 2001). The spectral response of vegetation indices will detect changes in pixel-level vegetation conditions (Leckie et al., 2005).

\subsection{Studies on Land surface Temperature (LST)}

In India, researches on land use/land cover have been done by various scholars, especially by using remote sensing data. Rose et al., (2009) analyses of land surface temperature and land use / land cover types using remote sensing imagery - a case in Chennai City, India. From the study it is evident that the heat island pockets are obviously going up, not only increased in area but also in intensity. The various land cover types such as high density built up spaces, medium density built up spaces, low density built up spaces, sparse vegetation, dense vegetation, barren land, marshy lands, water bodies etc. and the land use types such as the commercial, residential, industrial, institutional and open spaces contributes to the variation in temperatures leading to the formation of urban micro heat islands. Ramachandra et al., (2012) evaluate a study on land surface temperature analysis in an urbanizing landscape through multi- resolution data in Himachal Pradesh, India. Study revealed that there was a huge increase in urban area (including barren land), which is the causal factor for the changes in land surface temperature. An attempt has been made by Hussain et al., (2014) to analyze temporal variations in surface temperature in Ajmer District Rajasthan. The research is carried out to assess the relationship between the land surface temperatures (LST) and land cover (LC) changes both in quantitative and qualitative ways in Ajmer District area using Landsat TM/ETM+ data over the period 1989 to 2013.in this period we used three temporal TM/ETM data 1989, 2001 and 2013. Jeevalakshmi et al., (2017) estimate Land Surface Temperature from LANDSAT data using Emissivity Estimation in Chittoor district, Andhra Pradesh, India. Study focuses on developing an ERDAS IMAGINE image processing method using the LANDSAT 8 thermal imagery of band 10 data.

\subsection{Brightness Temperature Calculation}

The brightness temperature is a measurement of the radiance of the microwave radiation traveling upward from the top of the atmosphere to the satellite, expressed in units of the temperature of an equivalent black body. The Brightness Temperature (TB) is the fundamental parameter measured by passive microwave radiometers. The brightness temperatures, measured at different microwave frequencies, are used at Remote Sensing Systems to derive wind, vapor, cloud, rain, and Sea Surface Temperature (SST) products. Despite differences in sensor frequencies, channel resolutions, instrument operation and other radiometer characteristics, RSS produces high-quality, carefully inter calibrated data, using uniform processing techniques, with a brightness temperature data record spanning multiple instruments over several decades.

In the present study the land use/ land cover pattern and its changes over the study area was assessed using optical remote sensing during 2012 to 2017 and Land Surface Temperature (LST) of the years 2000, 2004, 2014 and 2017 were estimated respectively using remote sensing based overlaying method (Fig 1).

\section{MATERIALS AND METHODS USED FOR LAND USE/ LAND COVER CHANGES \\ 2.1 Data set used}

CNES/Airbus data (2000 and 2017) of the study area were collected from Google Earth API (Table 1).

\subsection{Software used}

Quantum GIS 2.18, ArcGIS 10.5 and Erdas Imagine 9.8

Table 1 Details of satellite data

\begin{tabular}{|l|l|l|}
\hline Specifications & \multicolumn{2}{|c|}{ Year } \\
\cline { 2 - 3 } & 2000 & 2017 \\
\hline Satellite & Digital Globe & Digital Globe \\
\hline
\end{tabular}




\begin{tabular}{|l|l|l|}
\hline Sensor & CNES/Airbus & CNES/Airbus \\
\hline
\end{tabular}

\subsection{Details of the thematic layers prepared}

The details of the thematic layers prepared for the study are given below (Table 2).

Table 2 Thematic Layers Prepared

\begin{tabular}{|c|c|c|}
\hline $\begin{array}{c}\text { Sl. } \\
\text { No: }\end{array}$ & Name of the Layers & Geometry \\
\hline 1 & $\begin{array}{c}\text { Land use and Land cover } \\
2000 \text { and } 2017\end{array}$ & Polygon \\
\hline
\end{tabular}

\subsection{Schematic Diagram Showing the Analytical Steps}

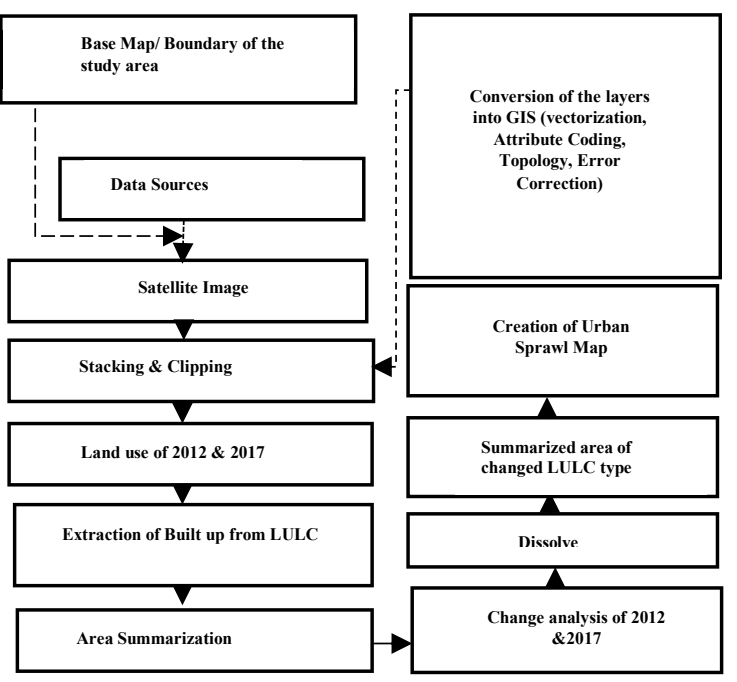

Figure 2 Scheme adopted for LULC change

- The High resolution images of the study area were downloaded from Google Earth API and the images were georeferenced in QGIS 2.8.

- The land use land cover of each layer was prepared, which shows the increase and decrease in various land use and land cover types.

- The land use land cover layers of different layers were overlaid by applying the' UNION 'overlay analysis function. It is very useful to understand the extent of changes occurred during the period between 2012 and 2017.

- The changed class codes for all the polygons were added to a new field in Feature Attribute Table (FAT) of the overlaid feature classes through concatenation of land use and land cover class codes of each overlaid years using field calculator.

- The spatial extend of each unique changed classes were computed through statistical summarization for quantification of results.
- Dissolve function from the Generalization of Data Management Tool was applied to the 'union' overlaid result using the concatenated attribute of each change from 2012 to 2017.

- The resulting attribute table provides the areas of new polygons that underwent changes in all the periods; from this area summarization was done to derive total area of each change classes.

\section{METHODS AND MATERIALS USED FOR BRIGHTNESS TEMPERATURE CHANGES}

\subsection{Data set used}

Landsat images (2000, 2004, 2014, and 2017) of the study area were collected from United State Geological Survey (USGS) (http://earthexplorer.usgs.gov) (Table 3). The spectral bands were stacked and geometrically corrected using Erdas Imagine 2015 software.

Table 3 Details of satellite data for LST calculation

\begin{tabular}{|c|c|c|c|c|}
\hline \multirow[t]{2}{*}{ Specifications } & \multicolumn{4}{|l|}{ Year } \\
\hline & 2000 & 2004 & 2014 & 2017 \\
\hline Satellite & $\begin{array}{l}\text { Landsat } \\
7\end{array}$ & $\begin{array}{l}\text { Landsat } \\
7\end{array}$ & $\begin{array}{l}\text { Landsat } \\
8\end{array}$ & $\begin{array}{l}\text { Landsat } \\
8\end{array}$ \\
\hline Sensor & ETM & ETM & ETM+ & OLI \\
\hline Bands used & $\begin{array}{l}6 \\
\text { (Thermal } \\
\text { band) }\end{array}$ & $\begin{array}{l}6 \\
\text { (Thermal } \\
\text { band) }\end{array}$ & $\begin{array}{l}10 \\
\text { (Thermal } \\
\text { band) }\end{array}$ & $\begin{array}{l}10 \\
\text { (Thermal } \\
\text { band) }\end{array}$ \\
\hline $\begin{array}{l}\text { Spatial } \\
\text { resolution }\end{array}$ & $30 \mathrm{~m}$ & $30 \mathrm{~m}$ & $30 \mathrm{~m}$ & $30 \mathrm{~m}$ \\
\hline
\end{tabular}

\subsection{Pre-processing}

The standard image processing technique of layer stacking, geometric correction and extraction were performed on two Landsat TM and OLI images collected for the study. The topographic map of scale 1:50000 surveyed in 1967 were used as reference map. All satellite images were geometrically corrected by this reference images.

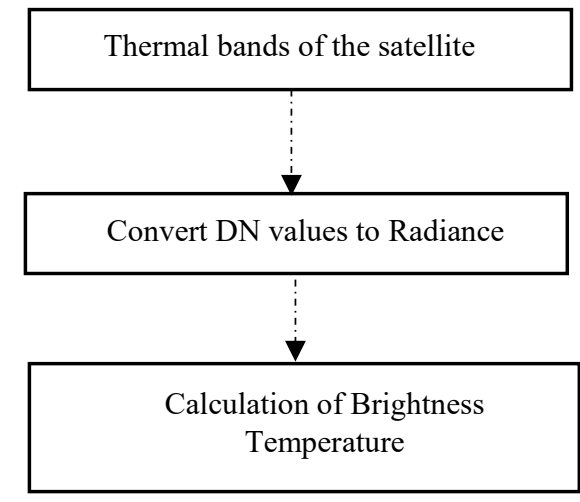

Figure 3 Scheme adopted for Brightness Temperature Calculation 


\subsection{DN in Radiance}

The reflectance value of NIR and Red bands were converted to radiance for avoiding the errors due to changes in the spectral ranges of bands used, which will lead to getting accurate values for quantitative factors. The equation was used for this study is given below (Eq.1) and (Eq.2)

For Landsat 5 TM,

\section{$\mathbf{L}_{\lambda}=($ LMAX-LMIN /QCALMAX - QCALMIN) $\mathbf{x}$ (QCAL-QCALMIN) + LMIN

Where

$\mathrm{L}_{\lambda}=$ Spectral radiance at the sensor's aperture in watts $/\left(\mathrm{m}^{2} \cdot\right.$ ster $\left.\cdot \mu \mathrm{m}\right)$

$\mathrm{QCAL}=$ quantized calibrated pixel value in DN (Digital Number)

LMIN = spectral radiance that is scaled to QCALMIN in watts $/\left(\mathrm{m}^{2} \cdot\right.$ ster $\left.\cdot \mu \mathrm{m}\right)$,

LMAX $=$ spectral radiance that is scaled to QCALMAX in watts/ $\left(\mathrm{m}^{2} \cdot\right.$ ster $\left.\cdot \mu \mathrm{m}\right)$.

QCALMIN $=$ minimum quantized calibrated pixel value (corresponding to LMIN) in DN.

QCALMAX is the maximum quantized calibrated pixel value (corresponding to LMAX) in DN.

\section{For Landsat 8 OLI}

$\mathbf{L} \lambda=\mathbf{M L} \times \mathbf{Q C A L}+\mathbf{A L}$

Where:

$\mathrm{L}_{\lambda}=$ spectral radiance at the sensor's (watts/ $(\mathrm{m} 2 \mathrm{x}$ sr $\mathrm{x}$ $\mu \mathrm{m}))$

ML = Radiance multiplicative Band (No.)

$\mathrm{AL} \quad=$ Radiance Add Band (No.)

QCAL $=$ Quantized and calibrated standard product pixel values $(\mathrm{DN})$

\section{RESULTS \& DISCUSSION \\ 4.1 Land use Land cover changes 2012 to 2017}

In 2012 most of the study area is covered with Mixed Tree with Settlement (MTS) and Water body. Mixed Tree with Settlement covers an area of 17.970 sq.km while water body covers 2.778 sq.km of area. While built-up and bare land covers an area of 0.914 and 0.0818 sq.km respectively. Ocean, white sand and beach covers an area of 0.884 , 0.0291 and 0.0565 sq. km. A small are of 0.05444 sq. $\mathrm{km}$ is covers with island (Table $4 \&$ Figure 4 ).

In 2017 also, most of the area is covered with mixed tree with settlement and water body with an area of 16.682 and 2.756 sq. km respectively. There is about 1.715 sq. $\mathrm{km}$ of area is covered with built ups. The barren land compresses an area of $0.3239 \mathrm{sq} . \mathrm{km}$. Ocean, white sand, beach covers an area of $0.9012,0.1308,0.1564$ sq.km respectively. While the island compresses of an area of 0.08377 sq.km (Table 5 \& Figure 5).

When the analysis of land use land cover change from 2012-2017 about 16.42 sq.km area of mixed tree with settlement remains as same. While some portion of the MTS changes to other land features. An area of 0.148 sq.km changes to water body. The remaining changes are as follows MTS to built ups 0.811, MTS-barren land 0.271 sq.km, MTS to ocean 0.037 sq.km, MTS to white sand 0.077 , MTS to Island $0.077 \mathrm{sq} . \mathrm{km}$ and MTS to beach area 0.106 sq.km. While in the case of water body 2.608 sq. km of area remains as same.an area of 0.146 sq.km changes to MTS. Other changes are as follows. Water body to built ups 0.001 , Water body-barren land 0.012 sq.km, water body to Island 0.005 sq.km, Water body to beach area 0.007 sq. $\mathrm{km}$. While in the case of built ups there is not that much of change about 0.896 sq.km of area remains as same an area of 0.016 and 0.002 sq.km changes to MTS and Island respectively. In the case of barren land also the changes are negligible an area of 0.035 sq. $\mathrm{km}$ remains as barren land. An area of $0.003 \mathrm{sq} . \mathrm{km}$ changes to Build ups and an area of 0.043 changes to MTS. When coming to the case of ocean about 0.858 sq. km area remain same. Other changes are as Follows Ocean to MTS 0.004, ocean-barren land 0001 sq.km, ocean-white sand 0.019 sq.km, ocean to beach area 0.003 sq. km. An area of 0.023 sq. km of white sand remains as same while an area of 0.006 sq.km changes to Beach area. In the case of Island an area of 0.050 and 0.004 sq.km changes to MTS and built ups respectively. Finally, in the case of beach area about 0.034 sq.km of area remains same the other changes are as follows beach area to barren land 0.005 sq.km, Beach Area to Ocean 0.006sq.km, beach area to white sand 0.012 sq.km (Table 6 \& Figure 6).

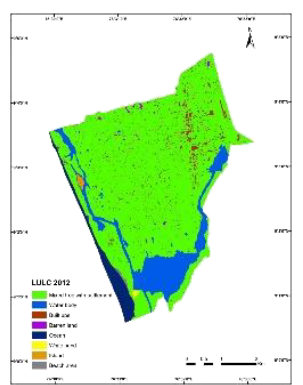

Figure 4 LULC 2012

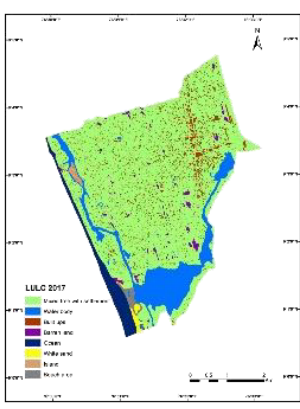

Figure 5 LULC 2017

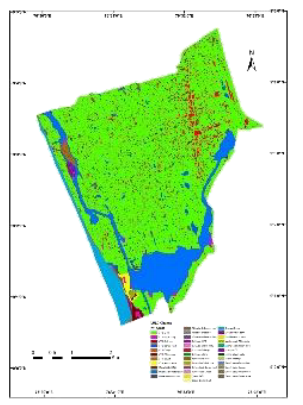

Figure 6 LULC 2012-2017 
Table 4 Land use land cover in 2012

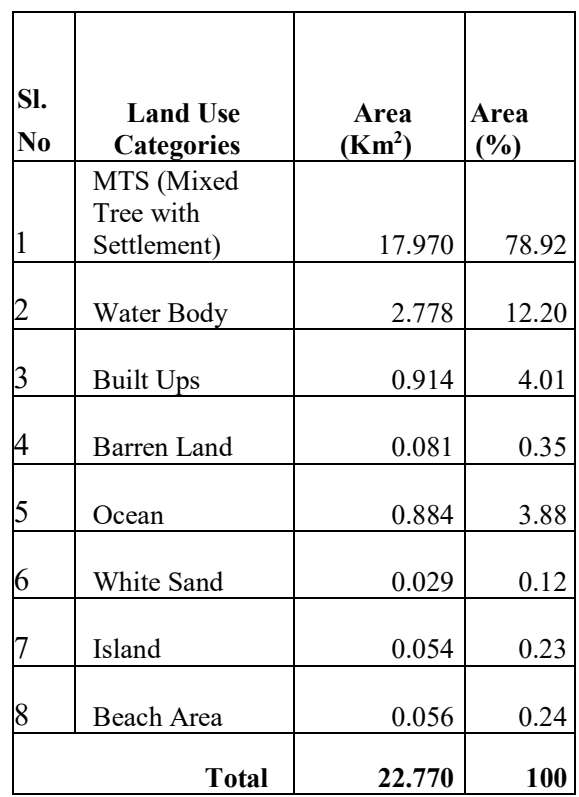

Table 5 Land use land cover in 2017

\begin{tabular}{|l|l|r|r|}
\hline $\begin{array}{c}\text { SI } \\
\text { No: }\end{array}$ & \multicolumn{1}{|c|}{$\begin{array}{c}\text { Land Use } \\
\text { Categories }\end{array}$} & $\begin{array}{c}\text { Area } \\
\left(\mathbf{K m}^{\mathbf{2}} \mathbf{)}\right.\end{array}$ & $\begin{array}{l}\text { Area } \\
\mathbf{( \% )}\end{array}$ \\
\hline 1 & MTS & 16.702 & 73.35 \\
\hline 2 & Water Body & 2.756 & 12.10 \\
\hline 3 & Built Ups & 1.715 & 7.53 \\
\hline 4 & Barren Land & 0.324 & 1.42 \\
\hline 5 & Ocean & 0.901 & 3.95 \\
\hline 6 & White Sand & 0.131 & 0.57 \\
\hline 7 & Island & 0.084 & 0.36 \\
\hline 8 & Beach area & 0.156 & 0.68 \\
\hline \multicolumn{2}{|r|}{ Total } & $\mathbf{2 2 . 7 7 0}$ & $\mathbf{1 0 0}$ \\
\hline
\end{tabular}

\subsection{Land surface Temperature}

In the year 2000 (27 September) the brightness temperature is high around the areas of highway, railway and coastal areas. In the case of 2004 (24 December) and 2014 (26 January) the brightness temperature is increasing around the highway and railway while the brightness temperature is decreasing in coastal areas. In 2017 (16 January), there is
Table 6 land use land cover change from 2012 to 2017

\begin{tabular}{|l|l|c|r|}
\hline $\begin{array}{r}\text { SI. } \\
\text { No }\end{array}$ & $\begin{array}{c}\text { Land use land cover } \\
\text { change categories }\end{array}$ & $\begin{array}{c}\text { Area } \\
\text { K }^{2} \text { ) }\end{array}$ & $\begin{array}{l}\text { Area } \\
\text { (ha) }\end{array}$ \\
\hline & Mixed Tree with & & \\
\hline. & Settlement (MTS)-MTS & 16.43 & 164.241 \\
\hline 2. & MTS-Water Body & 0.148 & 1.480 \\
\hline 3. & MTS-Built ups & 0.811 & 8.110 \\
\hline 4. & MTS-Barren Land & 0.271 & 2.709 \\
\hline 5. & MTS-Ocean & 0.037 & 0.374 \\
\hline 6. & MTS-White Sand & 0.077 & 0.768 \\
\hline 7. & MTS-Island & 0.077 & 0.773 \\
\hline 8. & MTS-Beach Area & 0.106 & 1.061 \\
\hline 9. & Water Body-MTS & 0.146 & 1.457 \\
\hline 10. & Water Body-Water Body & 2.608 & 26.080 \\
\hline 11. & Water Body-Built Ups & 0.001 & 0.007 \\
\hline 12. & Water Body-Barren Land & 0.012 & 0.125 \\
\hline 13. & Water Body-Island & 0.005 & 0.046 \\
\hline 14. & Water Body-Beach Area & 0.007 & 0.071 \\
\hline 15. & Built ups-MTS & 0.016 & 0.159 \\
\hline 16. & Built ups-Water Body & 0.000 & 0.001 \\
\hline 17. & Built ups-Built ups & 0.896 & 8.962 \\
\hline 18. & Built ups-Island & 0.002 & 0.019 \\
\hline 19. & Barren Land-MTS & 0.043 & 0.430 \\
\hline 20. & Barren Land-Built Ups & 0.003 & 0.033 \\
\hline 21. & Barren Land-Barren Land & 0.035 & 0.352 \\
\hline 22. & Barren Land-Ocean & 0.000 & 0.003 \\
\hline 23. & Ocean-MTS & 0.004 & 0.040 \\
\hline 24. & Ocean-Barren Land & 0.001 & 0.008 \\
\hline 25. & Ocean-Ocean & 0.858 & 8.575 \\
\hline 26. & Ocean-White Sand & 0.019 & 0.191 \\
\hline 27. & Ocean-Beach Area & 0.003 & 0.032 \\
\hline 28. & White Sand-White Sand & 0.023 & 0.229 \\
\hline 29. & White Sand-Beach Area & 0.006 & 0.062 \\
\hline 30. & Island-MTS & 0.050 & 0.502 \\
\hline 31. & Island-Water Body & 0.000 & 0.001 \\
\hline 32. & Island-Built Ups & 0.004 & 0.041 \\
\hline 33. & Beach Area-Barren Land & 0.005 & 0.045 \\
\hline 34. & Beach Area-Ocean & 0.006 & 0.060 \\
\hline 35. & Beach Area-White Sand & 0.012 & 0.121 \\
\hline 36. & Beach Area-Beach Area & 0.034 & 0.339 \\
\hline & & & \\
\hline
\end{tabular}

a sudden increase in the brightness temperature around the areas of highway and railway.

While analysing the brightness temperature of the Karunagappally municipality for the years 2000, 2004, 2014 and 2017 (Figure 7) there is a slight increase in temperature form the year 2000 to 2017 . The brightness 
temperature in the year 2000 ranges from $21.12^{\circ} \mathrm{C}$ to $31.05^{\circ} \mathrm{C}$. In the year 2004 , the temperature has increased to $23.4^{\circ} \mathrm{C}$ to $33.68^{\circ} \mathrm{C}$ while in the year 2014 the temperature range has reached $25.35^{\circ} \mathrm{C}$ to $33.65^{\circ} \mathrm{C}$. Finally, in the year 2017 the temperature has increased to $26.21^{\circ} \mathrm{C}$ to $36.24^{\circ} \mathrm{C}$. The changes in temperature may be due to the sudden urbanisation of the Karunagappally municipality.
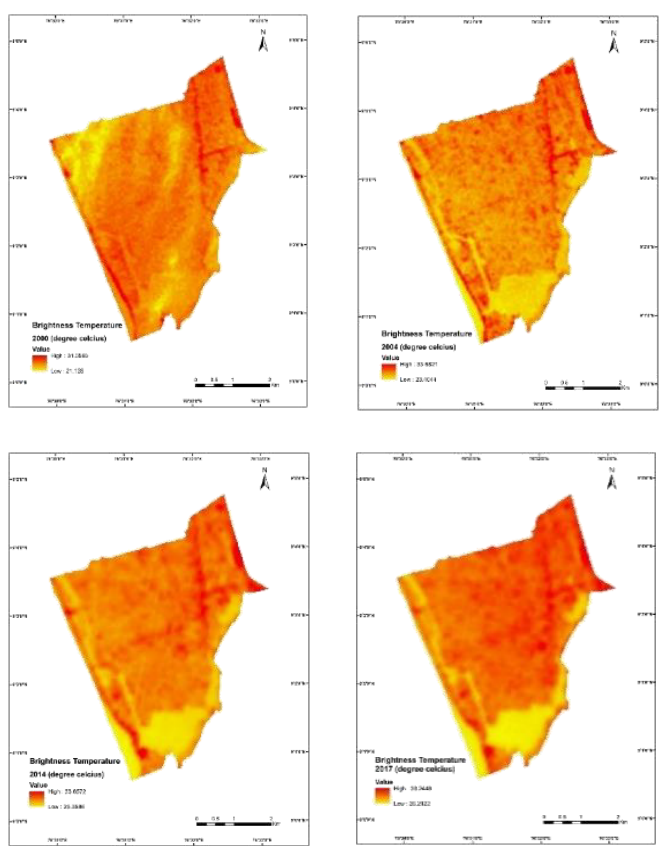

Figure 7 Brightness Temperature in the years 2000, 2004, 2014, and 2017 of the study area

\section{CONCLUSION}

The LULC pattern and its changes in the study area revealed that there is drastic urbanization happening in the area by converting natural habitats especially islands, water bodies and beach area. The present study was based on overlay methods to estimate the different land use land cover categories during the study period. Urbanization has a significant role in the changes of LST in the area. The Mixed tree with settlements were found to be increased over the years. Disturbance from industrial area and urbanization causes the degradation of vegetation leads to decreases in carbon storage of vegetation community around buildings. The variation of the surface temperature as a function of the different responses of the manmade features like highways and railways was clearly noticed in the increases of temperatures. The study area having large areas of mixed crop and coastal regions. Barren lands also covering good area and having large heterogeneously distributed patterns of settlements with anthropogenic activities in context to alteration of natural surface characteristics.

Due to the extreme abundance of vegetation in the area that reduced the radiation heat flux of the earth surface by consuming most of the radiation energy during the evapotranspiration process, the overall surface temperature was reduced as compared to the barren land and pure urban areas

\section{REFERENCES}

Bürgi M., Hersperger A. and Schneeberger N., 2004. Driving forces of landscape change - current and new directions. Landscape Ecology of Slovak Academy of Sciences 19, pp 857-868

Foley J.A., DeFries R., Asner G.P., Barford., Ford, A.C., Barr S.L., Dawson R.J. and James.P, 2017. Transport Accessibility Analysis Using GIS: Assessing Sustainable Transport in London.

ISPRS International Journal of Geo-Information. ISSN 2220-9964(2015). $\quad$ http://www.mdpi.com/22209964/4/1/124. Accessed on 08 September 2017

Hersperger A., Bürgi M., 2009. Going beyond landscape change description: quantifying the importance of driving forces of landscape change in a central Europe case study. Land Use Policy .26, pp 640-648.

Hussain A., Bhalla P. and Palria S., 2014. Remote sensing based analysis of the role of land use/land cover on surface temperature and temporal changes in temperature a case study of Ajmer district, Rajasthan. The International Archives of the Photogrammetry, Remote Sensing and Spatial Information Sciences, Volume XL-8, 2014 ISPRS Technical Commission VIII Symposium, $09-12$ December 2014, Hyderabad, India.

Jeevalakshmi. D., Reddy N. S., Manikiam B., 2017. Land Surface Temperature Retrieval from LANDSAT data using Emissivity Estimation. International Journal of Applied Engineering Research ISSN 0973-4562. 12(20) pp. 96799687

Lambin E.F., 1997. Modeling and monitoring land-cover change processes in tropical regions. Progress in Phys. Geography 21(3), pp 375-393

Leckie D.G., Cloney E., Joyce S.P.,2005 Automated detection and mapping of crown discoloration caused by jack pine budworm with $2.5 \mathrm{~m}$ resolution multispectral imagery. International Journal of Applied Earth Observation and Geoinformation 7, pp 61-77.

Martinez M.L., Pérez-Maqueo O., Vázquez G., CastilloCamposG., García-Franco J., Mehltreter K. \& Landgrave R., 2009. Effects of land use change on biodiversity and ecosystem services in tropical montane cloud forests of Mexico. Forest Ecology and Management . 258(9), pp 1856-1863.

Ramachandra T. V., Kumar U. and Joshi N. V., 2012. Landscape Dynamics in Western Himalaya-Mandhala Watershed, Himachal Pradesh, India. Asian Journal of Geoinformatics. pp 1-8 
Rose L. A. and Devadas M. D., 2009. Analysis of Land Surface Temperature and Land use / Land Cover types using Remote Sensing Imagery-A Case in Chennai City, India. The Seventh International Conference on Urban Climate.Yokohama. Japan

Satyanarayana B., Thierry D., Seen L., Raman A.V. and Muthusankar G., 2001. Remote sensing in mangrove research - relationship between vegetation indices and endocentric parameters: a case for Coringa, east coast of India. Proceedings of the Asian Conference on Remote Sensing, Singapore (5-9 November 2001). pp. 567-572.

Turner M.G., Gardner R.H., O`Neill R.V., 2001. Landscape ecology in theory and practice: pattern and process. Springer, New York. pp 401

Veldkamp A. and Verburg P.H., 2004. Modelling land use change and environmental impact.Journal of Environmental Management 72(1), pp 1-3.

Xiubin L. A, 1996. Review of the International Researches on Land Use/Land Cover Change. Acta Geographica Sinica 6. pp 553-558.

Zang S. and Huang X., 2006. An aggregated multivariate regression land-use model and its application to land-use change processes in the Daqing region (northeast China). Ecology Model 193, pp 503-516. 